\title{
Miša Đurković*
}

\section{GOJ AZNOST KAO POLITIČKI I TEORIJ SKI PROBLEM ${ }^{1}$}

\begin{abstract}
Apstrakt: Širenje gojaznosti i oboljenja koje ona prouzrokuje dovelo je do opravdanih upozorenja koja govore o epidemiji koja ozbiljno ugrožava zdravlje stanovništva u razvijenim zemljama. Autor polazi od klasičnog liberalnog određenja razlike između činova koji se odnose samo na delatnika i činova koji se odnose i na druge i postavlja pitanje kako se iz liberalne perspektive može posmatrati problem gojaznosti. Ukazujući na stvarne razloge koji izazivaju gojaznost, autor pravi razliku između apstraktnog liberalizma, koji ne vodi računa o kontekstu u kome se granica između dve vrste činova postavlja, i razvijenog, odgovornog liberalizma savremene liberalno-demokratske države koji na ovakav problem neosporno mora da reaguje. On, međutim, tvrdi da država $i$ dalje reaguje neadekvatno, jer pogrešno postavlja ideju o autonomiji individue (ili porodice) pa stoga uglavnom deluje na posledice, a ne na uzroke i izazivače.
\end{abstract}

Ključne reči: gojaznost, liberalizam, granice državne intervencije, hrana

Problem gojaznosti polako postaje jedno od najintrigantnijih pitanja koja potresaju zapadnu civilizaciju. U devetnaestom veku, kada se klasična liberalna teorija razvila i postepeno ustoličila kao osnovni pogled na svet u zapadnim zemljama (Abenlandes), Evropa i Amerika su još uvek muku mučile sa glađu. Veliki delovi stanovništva na ovim kontinentima još uvek su bili neuhranjeni. Ovo posebno važi za periferiju Evrope, što je dovelo do do sada najveće migracije stanovništva sa ovog kontinenta u Ameriku. U Irskoj je u doba velike gladi, polovinom veka, zbog elementarnog nedostatka hrane umrlo preko milion ljudi. Prekomerna težina u to doba

* Dr sc. Viši naučni saradnik, Institut za evropske studije

1 Članak je rezultat rada na projektu 179014, koji podržava Ministarstvo za nauku i obrazovanje Republike Srbije. On je delimično izmenjena i dopunjena verzija rada koji je prošle godine objavljen u filozofskom časopisu Theoria. 
nije postojala kao pojam. Štaviše, višak kilograma uglavnom je posmatran kao odraz dobrostojećeg položaja osobe. ${ }^{2}$

Tek stotinu godina kasnije, ista ova područja rešila su uglavnom problem gladi i neuhranjenosti, ali su otišla u drugi ekstrem: izvor novih problema postala je preobilna, prekomerna ishrana bazirana na namirnicama prezasićenim viškovima soli, šećera i štetnih hemikalija. Gojaznost kao deo „novog morbiditeta“ mladih (poremećaji seksualnog i reproduktivnog zdravlja, povrede i nasilje, zloupotrebe psihoaktivnih supstanci) je i problem sam po sebi, ali još više zato što vodi ka nizu sekundarnih oboljenja koja pogađaju kardiovaskularni sistem, reproduktivno zdravlje, izazivaju dijabetes itd.

Sve ono što se na tom području dešavalo u poslednjih nekoliko decenija dovelo je konačno do postepenog uvođenja prakse, prema kojoj država uzima sebi za pravo da roditeljima oduzima decu zbog navodnog zanemarivanja koje dovodi do njihove preterane težine i gojaznosti. U SAD je ova praksa već uspostavljena u nekoliko država, a u Britaniji je polovinom septembra 2011. sud doneo prvu takvu presudu kojom se uspostavlja presedan za slične metode ubuduće.

Ovaj problem je, razumljivo, počeo da intrigira i veliki broj teoretičara iz raznih oblasti, pa i filozofe. Dramatičan razvoj gojaznosti otvara mnoštvo pitanja iz etike, političke etike, pravne teorije, aksiologije i naročito političke filozofije. ${ }^{3}$

Namera autora u ovom tekstu jeste da najpre ispita kako klasična liberalna teorija posmatra problem opravdanog mešanja države u slobodu pojedinca, odnosno u domen privatnosti; zatim da istraži kako bi se iz te perspektive gledalo na problem gojaznosti, i na kraju, da ispita kako u okviru liberalne teorije možemo naći rešenje za efikasno suzbijanje ovog problema.

Kad se govori o liberalnoj političkoj teoriji neophodno je odrediti o čemu pričamo. Jedno moguće gledište jeste ostajanje u domenu čiste teorije koja barata apstraktnom argumentacijom i polazi od teze o apstraktnoj individui čija se apsolutna autonomija uzima kao nepobitna hipoteza. Ovaj okvir je možda zanimljiv teoretičarima koji sebe vide kao sledbenike izvornog liberalizma, ali nam on veoma malo pomaže u razumevanju stvarne prakse liberalnih demokratija.

2 Setimo se da se na karikaturama, krajem tog i početkom sledećeg veka, bogataši i kapitalisti predstavljaju kao debeli ljudi. Pogledati posebno karikature iz perioda boljševičke revolucije. Inače, još od renesanse se na slikama dobrostojećih ljudi uočava da su gojazni. I današnje statistike su pokazale da je gojaznost u siromašnijim zemljama prisutnija kod dobrostojećih, odnosno njihove elite, kao neka vrsta statusnog simbola.

Ovde potpuno ostavljam po strani veoma popularan diskurs o biopolitici zbog previše nejasnog određenja same „oblasti“ istraživanja, kao i zbog potrebe da se problem sagledava iz izvorne liberalne perspektive, dok je biopolitika uglavnom vezana za radikalno levu tradiciju čije normativne postavke implicitno usvaja. 
Drugo gledište, koje autor usvaja, smatra da je liberalna politička teorija jedan evolutivni korpus mišljenja i argumentacije, koji se sastoji od kanonskih tekstova mislilaca kao što su Kant, Konstan ili Mil, ali takođe i od ukupne zakonodavne, sudske i moralne prakse država koje se nazivaju liberalno-demokratskim. Ovo gledište ima daleko složenije shvatanje prirode ljudske individue čija se autonomija ne uzima kao činjenica data rođenjem, odnosno prostom činjenicom postojanja (uz izuzetke maloletnih i maloumnih osoba), već se pre smatra zadatkom, normativnim ciljem koji država i društvo treba da pomažu, grade i brane s jedne strane, i, s druge, pravnom stimulacijom, neophodnim uslovom legitimnog pripisivanja odgovornosti koji omogućava funkcionisanje tržišne privrede i čitavog pravnog sistema. Iz ove perspektive, liberalna teorija se posmatra kao evolutivni sistem, istraživački, teorijski i praktični program koji se neprestano dorađuje, preispituje i razvija, baštineći ipak neke osnovne principe koji čine jezgro liberalizma kao ideologije. Značaj liberalizma za savremenu, pre svega zapadnu civilizaciju je fundamentalan. U poslednjih sto do sto pedeset godina liberalizam je u većini država zapadnog sveta postao osnovna „bekgraund“ teorija koja definiše ustavnopravni okvir. Zbog toga se sam taj sistem naziva liberalna demokratija, a socijalističke i konzervativne grupacije, koje se smenjuju na vlasti, u suštini funkcionišu prihvatajući elementarna načela liberalne teorije.

Suština liberalno-demokratskih društava se, bez obzira na brojne varijacije, vrlo lako može opisati. To su, s jedne strane, demokratska društva u kojima se vlast bira na relativno slobodnim izborima između više ponuđenih opcija, a vladu formira onaj ko dobije većinsku podršku birača izašlih na izbore. S druge strane, to su liberalna društva zato što se smatra da su, bez obzira na to ko čini većinu i kakvu politiku želi da sprovodi, neka fundamentalna prava uglavnom ${ }^{4}$ nedodirljiva.

Klasična post-prosvetiteljska liberalna teorija, kakva je Milova izložena u spisu O slobodi, za razliku od prosvetitelja koji barataju sa idejom prirodne harmonije interesa, podrazumeva konflikt i razlike kao neizbežne sastojke modernih društava. Ona stoga kao ključni problem, odnosno zadatak za svaku teoriju i praksu koja se razvija unutar takvih društava, postavlja pitanje granica opravdanog delanja države i vlasti prema pojedincu.

Ovde treba podsetiti da se i sam Milov opus i spis $O$ slobodi moraju dati objektivno, dakle nemanipulativno, kako to, nažalost, postaje uobičajeno. Esej $O$ slobodi sastoji se od pet poglavlja, od kojih su prva tri posvećena iznošenju argumentacije u prilog opravdanja i odbrane individualne slobode. Veoma je važno i tu zapaziti da Mil

\footnotetext{
S obzirom na to da su i liberalne demokratije države koje deluju u složenim međunarodnim okolnostima, čak i one poznaju slučajeve kada se svako pravo, pa i ona fundamentalna humanitarna mogu pogaziti: državni razlog, vanredno stanje, privremena suspenzija ustava i zakona, fundamentalni zahtevi bezbednosti, izopštenje pojedinaca iz čitavog sistema u slučajevima borbe protiv terorizma, mučenja zarad iznuđivanja priznanja, vođenje crne propagande, false flag akcije, zatim eksproprijacija zemljišta itd.
} 
mnogo polaže na instrumentalnu, utilitarnu i pragmatičku vrednost slobode, dakle da ona nije apsolutno dobro po sebi već instrumentalno dobro koje doprinosi blagostanju, razvoju civilizacije dobrom životu i sveukupnom napretku. I do dan-danas ova tri poglavlja se s pravom smatraju klasičnim i najsažetijim štivom kad je u pitanju argumentacija u prilog individualne slobode.

Ipak, još zanimljivija su poslednja dva poglavlja. Manipulativno iznošenje Mila, koje pokušava da ga predstavi kao naslednika prosvetiteljske škole o prirodnoj harmoniji interesa, najčešće u potpunosti ignoriše ova dva poglavlja. Ona se, međutim, bave ključnim zadatkom za koji Mil jasno uviđa da svako društvo ponovo mora samo za sebe da ga rešava ispočetka, u skladu sa mnoštvom onih uslova i spoljnih okolnosti koje bi apstraktna teorija lakonski otpisala kao uslov ceteris paribus. Četvrto poglavlje nosi naslov „O granicama vlasti društva nad pojedincem“, a peto „Primene“, koje uglavnom donosi primere dozvoljenog mešanja. ${ }^{5}$

Mil je, naime, još u prvom poglavlju izneo ključnu liberalnu distinkciju između činova koji se odnose samo na pojedinca i činova koji se odnose i na druge. U često citiranim redovima on tvrdi kako nastoji da nađe veoma prost princip koji bi regulisao prinudu ili kontrolu, bilo da je u pitanju fizički pritisak ili moralni pritisak javnog mnjenja. Princip, kao što je poznato, tvrdi da je jedini cilj koji opravdava mešanje samoodbrana, tj. sprečavanje pojedinca da povredi druge (takozvani princip štete, harm principle) ${ }^{6}$

Sloboda pojedinaca, koja je prima facie uslov za napredak i blagostanje društava i civilizacije, mora biti pravilo, norma, a svako njeno ograničavanje mora se iz te perspektive posebno opravdavati (što bi bio legitimni i dozvoljeni paternalizam u određenim slučajevima). Instrument za sprovođenje ovakvog principa jeste distinkcija između činova koji se odnose samo na osobu i činova koji se odnose na druge (self regarding i others regarding acts). Mil tvrdi da je samo ponašanje koje se tiče drugih ono za koje smo odgovorni prema društvu. U ponašanju koje se tiče samo mene ja sam apsolutno nezavisan. Ukratko, nad sobom, svojim telom i duhom, pojedinac je suveren. ${ }^{7}$

U doba kada su nastajali klasični tekstovi liberalne političke filozofije, porodica se posmatrala kao domen apsolutne privatnosti. Jedna od distinktivnih odlika liberalizma u odnosu na konzervativizam i socijalizam dugo je bila upravo ova odbrana porodičnog domena od nastojanja države i društva da se meša u unutrašnje odnose u porodici, da im postavlja norme i prioritete, kao i da određuje kako će vaspitavati i podizati svoju decu. ${ }^{8}$

$5 \quad$ Treba se podsetiti da je Milov važan preteča u postavljanju problema određenja i iscrtavanja ove granice Vilhelm Fon Humbolt, čiji značajan spis nosi naslov Ideje za pokušaj određivanja granica delotvornosti države. Videti Humbolt (1991).

6 Mil (1998), str. 42.

7 Isto, str. 43.

8 Feministička tradicija npr. i dan-danas insistira na novom modelu brige i staranja za svakog pojedinca, što navodno treba da bude zadatak društva, nasuprot liberalizmu koji je, po njima, odbranom 
Poslednja dva poglavlja spisa $O$ slobodi veoma dobro ilustruju činjenicu da su i sami liberali bili svesni koliko je ova načelna distinkcija između privatnih i javnih činova teška za primenu. U njenom nalaženju i određivanju de fakto sudeluju svi zainteresovani članovi jednog društva, mediji, javno mnjenje i institucije, uključujući i zakonodavne i pravosudne organe. To najbolje ilustruje evoluciju liberalizma u poslednjih vek i po usko vezanu za evoluciju prakse liberalno-demokratskih tvorevina.

Već u doba kada Mil piše svoje ključne spise, dakle polovinom veka, dešava se transformacija koja je poznata kao liberalizam na vlasti. Dolazak Liberalne stranke na vlast u Britaniji, kao i učešće francuskih doktrinara (Gizo, Roje-Kolar, De Baran) u upravljanju državom, znatno je pomerilo viziju sveta sa kojom su oni nastupali. Boravak na vlasti podrazumevao je i mnogo više odgovornosti, te prihvatanje nužnosti da se određena politička prava ograniče u načelu, stave pod kontrolu ili rezervišu samo za određene delove društva (što je uglavnom rešavano preko institucije imovinskog cenzusa). Cenzura štampe, ograničavanje prava na okupljanje i štrajkovanje, ograničavanje prava glasa na manji broj populacije, ili restriktivni zakoni koji regulišu tržište rada, postali su praksa režima koji su poticali iz liberalnog političkog spektra.

Pola veka kasnije, početkom dvadesetog veka, novi ili neoliberalizam u Britaniji (Hobhaus, T. H. Grin, Hobson) dobio je jedan dosta drugačiji oblik i sadržaj koji je sledio i prihvatio rezultate prakse zapadnih režima. Ova praksa je, težeći ka klasnom kompromisu i integraciji ogromne mase seljačkog i posebno novog gradskog stanovništva, u politički mainstream ili maticu prihvatila modele socijalnog zakonodavstva koji su legitimisali brigu države za mnoge sektore i aspekte privrednog i društvenog života, kakvi bi ranijim liberalima izgledali poput svetogrđa. Takva tendencija, velikim delom dopunjena i postignućima totalitarnih režima koji su napravili ogromne rezultate u širenju zdravlja, obrazovanja i socijalne i društvene integracije (naravno za one kojima je priznato pravo građanstva), svoju kulminaciju dobila je u razvoju posleratne države blagostanja.

Ako se zanemari prigovor libertarijanaca koji posleratnu zapadnu državu doživljavaju kao socijalističku, ogromna većina teoretičara složiće se da se ove države s pravom mogu nazvati liberalno-demokratskim. Uprkos tome što su ekonomske i preduzetničke slobode ograničene pre svega visokim porezima, a često i progresivnom poreskom stopom, išlo se ka stalnom širenju i garantovanju individualnih političkih prava i participativnih prava. Države su sve više preuzimale brigu o zdravlju, obrazovanju, naučnom i tehnološkom razvoju i infrastrukturi, postižući velike rezultate. Ovakav razvoj doveo je i do promena na ideološko-političkom spektru, pa je npr. u Sjedinjenim Državama u poslednjih pola veka uspostavljena praksa da se liberalima nazivaju oni mislioci, praktičari i političari koji se, s jedne strane, zalažu za veću državnu intervenciju u privredi i socijalnoj zaštiti, za više poreze, za veća prava

nedodirljivosti privatnog domena sankcionisao unutarporodične nepravde i potčinjen položaj žene i dece prema muškarcu. 
manjinskih grupa, kao i za podsticanje različitih oblika izražavanja svog identiteta u javnom prostoru. Njima se suprotstavljaju tradicionalisti i konzervativci koji traže veće ekonomske slobode, manje poreze $i$, $s$ druge strane, više zaštite za tradicionalnu porodicu i njen model... Naš zadatak ovde otežava činjenica da se američki liberali prepoznaju po tome što zahtevaju sve više intervencije države u porodičnu sferu i sve veće narušavanje klasičnog porodičnog okvira do mere da im to postaje gotovo totalitarna opsesija. Stoga ću se ovde držati umerenog shvatanja liberalizma koje je bliže onome što se danas u Evropi smatra liberalnom praksom i teorijom.

Prethodni istorijski okvir trebalo je da pokaže da su se tokom evolucije liberalizma zaista u velikoj meri pomerile granice između činova koji se odnose na sebe i one koji se odnose na druge. Međutim, čini se da je, u skladu sa liberalnim pogledom na svet, zahtev da se toj tendenciji nađe mera da se sama bazična distinkcija sačuva: u duhu klasičnog liberala i kad prihvata neophodnost intervencije jeste borba za odbranu i proširenje domena slobode a za ograničavanje nepotrebnog i posebno opasnog paternalizma. Slučaj gojaznosti, kojim se ovde bavim, čini se da je jedan od tih graničnih slučajeva koji zahteva ozbiljno promišljanje, kao i borbu za ograničavanje veoma opasne tendencije države da ovaj problem uzme kao pretekst i opravdanje za neke nove vidove mešanja u domen porodice i privatnosti.

Problem gojaznosti polako postaje jedno od najurgentnijih pitanja u javnoj sferi najbogatijih zemalja. Gotovo svakodnevno u medijima je moguće naći mnoštvo vesti i podataka koji govore o frapantnoj tendenciji porasta broja gojaznih osoba, predviđanja o tome koliko će se ove brojke uvećati u narednih dvadeset do pedeset godina i apele da se ovi problemi uoče i na neki način suzbiju.

Čini se da je ova vrsta tematike počela da se probija u medije u prvoj polovini prethodne decenije. Relevantna istraživanja pokazuju da se gojaznost postepeno širila i uvećavala počev od druge polovine osamdesetih, da bi tokom devedesetih konstantno rasla. Oko 2000. već je fenomen uočen i apostrofiran ${ }^{9}$, da bi tokom naredne decenije sa kontinuiranim porastom problema narasla i količina prostora koji se u medijima toj tematici posvećuje. Danas to već povremeno podseća na moralnu paniku koja proizvodi sve veće zahteve da se država i pravni sistem umešaju i počnu planski da suzbijaju ovaj izazov. ${ }^{10}$

Kako se liberalna teorija može odnositi prema ovom problemu? Savremeni diskurs levice barata sa terminom neoliberalizam kao sa univerzalnim strašilom koje je krivo za sve vrste zala koje postoje u savremenom svetu, a posebno za kapitalni zločin

$9 \quad$ Već 2001. objavljene su analize i studije koje su počele da govore o globalnoj epidemiji gojaznosti.

10 Čak je i prva dama SAD, Mišel Obama, na čelu jedne od organizacija koje se bore protiv gojaznosti. 
deregulacije, koji je navodno ubio državu blagostanja. Najčešće se ovaj pojam koristi bez preciznog određivanja pa se pod njega podvode i ekonomski liberalizam, koji promoviše slobodno tržište, i politički liberalizam, koji barata sa zaštitom političkih prava pojedinaca, i institucionalni neoliberalizam u međunarodnim odnosima, koji navodno podriva suverenitet država. To što neko može da bude politički ili ekonomski liberal, a realista u međunarodnim odnosima u principu se ignoriše.

Dakle, za levičare je smrt države blagostanja, kao rezultat neoliberalne propagande, kriva i za pojavu epidemije gojaznosti. ${ }^{11}$ Neoliberali su naprosto sluge velikih korporacija koje omogućavaju legitimaciju reklamokratije i podsticanja prekomerne ishrane, kao osnovnih instrumenata kojima kompanije eksploatišu stanovništvo, stiču profit i stvaraju probleme društvu i državi. Tvrdi se, između ostalog, da je neoliberalni diksurs učinio mnogo da se država liši brige o zdravlju stanovništva i da se staranje o tom segmentu razvoja čitave populacije, a posebno dece prenese na same stanovnike odnosno na roditelje.

Na ovom mestu želim da razjasnim sopstvenu poziciju o uzrocima gojaznosti. U najvećem delu slažem se sa goreiznetom naracijom, odnosno sa opisom činjenice da ogromne kompanije suzbijaju ulogu države zaštitnika u ime profita. U poslednjih dvadesetak godina čitava društvena atmosfera brige o zdravlju se značajno pogoršala. Počnimo od bivših socijalističkih zemalja. U njima, kao u svim totalitarnim sistemima, briga o zdravlju nacije bila je visoko pozicionirana na lestvici vrednosti i zadataka države. Kroz čitav sistem školskog obrazovanja i redovne vojne obuke fizička sprema je imala značajno mesto i posvećivano joj je mnogo vremena. ${ }^{12}$

Nakon sloma komunizma čitav ovaj sistem je radikalno promenjen, a sportskim i fizičkim aktivnostima u obrazovanju posvećuje se mnogo manje pažnje. Profesionalni i vrhunski sport preuzeli su veliku količinu resursa, dok se osnovnoj fizičkoj kulturi čitave populacije posvećuje mnogo manje pažnje i u nju se mnogo manje investira.

S druge strane, ove zemlje su doživele snažan upliv reklamokratije. Ona je čak i u zapadnim zemljama, sa razvojem i širenjem interneta, doživela neslućene razmere. Čitav javni prostor u oba nekadašnja bloka okupiran je od strane reklamnih agencija koje nam svakodnevno uvaljuju mnogobrojne suvišne proizvode upakovane u neodoljivu oblandu, servirane tako da im je nemoguće odoleti. Globalizacija, kao proces širenja unifikovanih proizvoda malog broja džinovskih multinacionalnih kompanija, dovela je do prave presije nad čulima i osećajima stanovništva u svim krajevima sveta. Jedan od najvažnijih izvora gojaznosti, pored smanjene fizičke aktivnosti stanovništva, jeste činjenica da velike kompanije, poput Pepsija, Nestle, Koka Kole, Mekdonaldsa

11 Videti argumentaciju u Callaghann, (2011).

12 Sovjetski Savez u svojoj kasnijoj fazi čini delimičan izuzetak zbog vrlo specifičnog masovno raširenog alkoholizma koji je smanjivao životni vek i radnu produktivnost stanovništva. No, i to je neuporedivo sa kataklizmom koja se desila nakon 1991. u Rusiji. 
itd., ostvaruju ogromne profite na proizvodnji i prodaji nezdrave hrane. Uočeno je da se prosečna porcija hrane uvećala duplo za svega dve decenije. ${ }^{13}$

Naravno, u samoj činjenici pravljenja profita ne postoji ništa loše. Štaviše. Međutim, ove kompanije su suštinski doprinele atmosferi u kojoj se hrana ne tretira kao osnovna ljudska potreba koju njihova ponuda treba kvalitetno da zadovolji. ${ }^{14}$ Obrnuto, hrana se tretira kao neka vrsta droge. Savremena nauka i tehnologija koriste se za stvaranje hrane i napitaka čija je nutriciona vrednost minimalna, a proizvodnja najjeftinija moguća. Najveći deo budžeta u radu takvih kompanija daje se za reklamu koja treba da podstiče primaoce poruka da se što više hrane u njihovim restoranima i da jedu što više. Monstruozni budžeti koje Koka Kola i Pepsi izdvajaju za reklamiranje svojih osnovnih, po zdravlje veoma štetnih proizvoda, služe za iznajmljivanje najvećih sportskih i estradnih zvezda koje treba da kod mladih, čiji su idoli, podstaknu potrebu za konzumiranjem upravo tih pića.

Osim ovih nezdravih napitaka, gojaznost šire i restorani brze hrane koja se proizvodi u strahovitoj količini ulja i masti. U poslednjoj deceniji raširila se, međutim, još strašnija pojava podsticanja proždrljivosti: restorani koji funkcionišu po principu ,plati i jedi koliko možeš“. Do pre pojave poslednje krize iz 2008, hrana je postala izuzetno jeftina i to posebno ova nezdrava. Lanci restorana su, međutim, uveli i ovo novo podsticanje ljudi da svoju proždrljivost (u hrišćanstvu je ona jedan od sedam smrtnih grehova) razvijaju do neograničenih dimenzija.

Druga vrsta korporacijskog doprinosa gojaznosti stiže od tehnoloških giganata. Nakon dominacije televizora, igrica i interneta sa društvenih mreža, koji su već i previše privezali decu i adolescente za stolice, krevete i domove, širi se nova tehnološka revolucija malih nomadskih instrumenata, tzv. gedžeta ( $\mathrm{Pad}$, mobilni telefon kao mini kompjuter, eBook Reader) koji će učiniti da deca i van kuće, dakle u svakom trenutku, budu vezana za ekran i umrežena u svojevrsni virtuelni Matriks. ${ }^{15}$ Ovom kulturom slike, koja dominira u doba globalizacije, deca i adolescenti će dodatno smanjiti vreme koje provode u kretanju, sportu ili direktnoj komunikaciji sa drugima. Posledice ove nove tehnološke revolucije biće opasne ne samo s aspekta gojaznosti već i s aspekta agresivnosti, neuravnoteženosti i pada kreativnosti i imaginacije. ${ }^{16}$

13 Vidi Banićević i dr, (2007), str. 9. Posebno je važno istaći činjenicu da su ove predatorske kompanije usmerene na adolescente kao podložnije reklamama jer time stiču dugoročnu klijentelu. Mnoga istraživanja su pokazala da su gojaznija deca mnogo češće gojazni odrasli.

14 Zanimljivo je da ove kompanije prednjače i u promovisanju nekih drugih „progresivnih“ tendencija koje suštinski menjaju naša uobičajena shvatanja. Mekdonalds je 2010. u Francuskoj među prvima lansirao marketinšku kampanju okrenutu homoseksualnoj populaciji.

15 Nesporno je utvrđena direktna veza između dužine gledanja televizora i porasta gojaznosti.

16 Rubino se s pravom zalaže za istraživanje uticaja svih aspekata globalizacije na razvoj mozga i mišljenja kod dece i adolescenata. Radi se zaista o nekoj vrsti šoka budućnosti, o čemu se pisalo još početkom sedamdesetih. Ovaj autor govori i o evidentnom uticaju globalizacije ishrane i takozvane nutricione tranzicije kao značajnim uzrocima gojaznosti. Vidi Rubino (2010), str. 11. Lokalna ishrana je uvek bila prilagođena specifičnom prostoru, atmosferskim prilikama, radnim navikama stanovništva, 
Sledeća vrsta doprinosa stiže od izmene strukture porodice i porodičnih odnosa, koja je na zapadu radikalno sprovedena u poslednjih pola veka, čemu je feminizam dao suštinsku ideološku podršku i legitimaciju. Dok je majka ostajala kod kuće da brine o deci to je značilo i domaću hranu, redovne i uglavnom zdrave obroke. Danas, kada su žene takođe izbačene na tržište rada potpuno se promenio sistem ishrane. Dominira brza hrana koju članovi porodice konzumiraju van kuće. To znači višak masti, belih testenina, šećera i soli, a manjak mlečnih proizvoda, voća i bilo kakvog, a naročito svežeg povrća. Svesne katastrofalnih posledica ove transformacije, od kojih su korist imale pre svega najveće kompanije zbog veće konkurencije na tržištu rada, neke feministkinje pokušavaju da ukazuju na neadekvatan tretman kućne brige kao posla koji bi država trebalo posebno da plaća, što bi možda bar neke roditelje vratilo u dom i obnovilo porodicu. Ti zahtevi se poklapaju sa dugogodišnjim zalaganjem pojedinih kozervativaca, poput Alana Karlsona, da se ozbiljno istraže iskustva takozvane porodične nadnice i porazmisli o mogućnostima njenog oživljavanja.

U svakom slučaju, najveći krivci za širenje gojaznosti danas zaista jesu kompanije koje koriste nedostatak regulacije u određenim oblastima da bi proizvodnjom jeftine i nezdrave hrane, njenom širokom dostupnošću i propagiranjem koje manipuliše ljudima ostvarivale ogromne profite. Cenu njihovog profita, po pravilu, plaća čitavo društvo. Njihovo ponašanje i posledice koje proizvode zaista odgovaraju shemi koju je u knjizi Velika transformacija izneo Karl Polanji: kompanije koje kao jedino merilo imaju profit iskoristiće svaki prostor da ga stvore često nanoseći društvu nemerljivu štetu. U ovom slučaju, profit kompanija stvara se po cenu velike moralne, finansijske, produktivne i bezbednosne štete koju trpe društvo i država.

Libertarijanci bi na ovo odgovorili kao na pogrešno postavljenu tezu. Tvrdeći da slede klasični i jedino ispravan vid liberalizma, oni bi na ovakve primedbe odgovorili da je pojedinac jedini odgovoran za sopstvene postupke i da niko ne može da bude kriv za činjenicu da neko uzima više hrane nego što mu je potrebno i time povećava sopstvenu težinu. Na slobodnom tržištu kompanije imaju potpuno legitimno pravo da prave profit i proizvode hranu kakvu god one žele pod uslovom da ona nije direktno opasna po organizam (otrovna npr., ili da se ne radi o namirnicama kojima je prošao rok). Dakle, svi vidovi podsticanja proždrljivosti bili bi, po njima, sasvim legitimni jer je autonomna osoba sama jedina kompetentna da odluči o tome šta će od toga izabrati i u kojoj meri. Iz ove perspektive čovek ima puno pravo da izabere da bude debeo, da jede koliko hoće, a o stanju svog zdravlja jedino je on meritoran da odlučuje. Dakle, isključivo mikropristup je legitiman jer se pretpostavlja da je takva mikropolitika koja pojedinca doživljava kao apsolutno autonomnu osobu najbolja i za makronivo. Polaženje od makronivoa, državnog ili nacionalnog interesa, koji smatra

bogatstvu zemlje itd, i nastajala je hiljadama i stotinama godina postepenom metodom prilagođavanja. Danas se ona sistematski suzbija globalizacijom iste, uglavnom nezdrave hrane tako da u organizmima dece i ljudi dolazi do pravog revolucionarnog sukoba genetskih predispozicija i novih materija i nutricionih navika. 
da je u interesu bezbednosti zemlje neophodno da država vodi računa o zdravlju svojih stanovnika, libertarijancima je prihvatljivo taman koliko i svaka politika države koja podstiče demografiju suprotno željama samih individualnih stanovnika. Dakle, svaka takva politika bila bi tumačena kao nedopustivi paternalizam, kolektivizam, pa čak i fašizam.

Savremeni levičari upravo ovakav libertarijanizam, koji nazivaju neoliberalizmom, smatraju jedinom vrstom odgovora liberalizma na pitanje gojaznosti. Polazeći od složenijeg shvatanja klasičnog liberalizma, o kome sam govorio na početku teksta i kakav sam razvijao u knjizi Kapitalizam, liberalizam i država, ${ }^{17}$ pokušaću da ispitam kako bi iz perspektive klasične kapitalističke liberalno-demokratske države, dakle razvijenog i punog liberalizma, mogla da izgleda savremena liberalna politika prema problemu gojaznosti.

Liberalna država je, pre svega, država koja funkcioniše u sistemu međunarodnih odnosa, i dalje fundamentalno određenom odnosima anarhije, snage i moći. Radi se o sistemu u kome se države, u krajnjoj liniji, najviše oslanjaju na samopomoć. Ovo nije samo gledišTe realista već neosporna praksa kojoj čak i vodeći liberalni institucionalisti ne mogu mnogo da prigovore. Kao što je poznato, i vodeći neoliberalni teoretičari međunarodnih odnosa (Naj, Kiohejn, Dojl) prihvataju realističke postavke o anarhičnoj strukturi međunarodnih odnosa koju bi postepeno uspostavljanje regionalnih i međunarodnih režima i institucija bar delimično trebalo da uvede u red i reguliše.

Ako se pođe od ove činjenice u kojoj je opstanak države, dakle bezbednost, prvi i najvažniji cilj svake pa i liberalne države, onda se za takvu državu postavlja kao legitiman i čak neophodan zadatak da brine o veličini populacije (da vodi demografsku politiku) i da vodi računa o zdravstvenom stanju te populacije (dakle, da vodi zdravstvenu politiku). Ako se ove premise prihvate (anarhisti, fundamentalne kosmopolite i libertarijanci ih, kao što znamo, ne prihvataju) onda se postavlja pitanje načina na koji se ovi zadaci mogu ostvariti.

Normativni duh individualističkog liberalizma tvrdio bi da su pojedinci najbolje sudije u stvarima koje se tiču samo njih. Dakle, pitanje moje težine je moje lično pitanje. Ako se pođe od hipoteze o autonomiji i racionalnosti odraslih osoba, onda bi zaista sledilo da će ukupno stanje zdravlja populacije u nekoj zemlji najbolje biti ostvareno ako svaki pojedinac sam vodi računa o sopstvenom zdravlju, određuje šta i koliko jede, kao i koliko se bavi fizičkim aktivnostima.

$\mathrm{S}$ druge strane, činjenica je da se čitava društvena i ekonomska atmosfera u kojoj pojedinac obitava promenila od vremena kad su ovi normativi postavljeni. Na

$17 \quad$ Vidi Đurković (2005). 
primer, tada je velika većina stanovništva još uvek živela od poljoprivrede koja je podrazumevala konstantan naporan fizički rad, dakle stalnu fizičku aktivnost. Isto važi i za većinu nepoljoprivrednih poslova u rudarstvu i tadašnjoj industriji. Zapravo je vrlo mali broj ljudi tada radio u delatnostima koje ne uključuju stalne fizičke aktivnosti. Danas, međutim, u poljoprivredi radi manje od deset procenata stanovništva, u prilično automatizovanoj industriji oko dvadesetak procenata i čak sedamdeset posto u sektoru usluga koji, po pravilu, ne uključuje nikakav fizički rad. Dakle, najveći broj zaposlenih provodi svoje radno vreme bez fizičkih aktivnosti. Ne slučajno, širenje gojaznosti se velikim delom poklapa sa povećanjem broja populacije koji radi u sektoru usluga.

Osim toga u to doba, sve do šezdesetih godina, u ovim zemljama je i dalje postojala oskudica hrane, posebno mesa. Danas je ponuda hrane preobilna a njen sastav mnogo gori nego u ranijem periodu.

Treće, u to doba su moralne i religiozne stege u društvu bile daleko jače i prisutnije. Kako je Gramši u čuvenom uvidu primetio, zapadni svet je bio implicitno natopljen sa dve hiljade godina hrišćanstva koje je, između ostalog, zabranjivalo prežderavanje i u kome je post, uzdržavanje od hrane i pića, bio osnovni način samopročišćenja i samodiscipline. Porast gojaznosti takođe koincidira sa rastom sekularizacije i odaljavanja od hrišćanskih naloga discipline, uzdržavanja i mere.

I kao vrhunac čitavog procesa u odnosu na tadašnji period pojedinac je svakodnevna žrtva manipulativne reklame. Njegova autonomija ranije nije bila toliko ugrožena heteronomijom razorne, na naučnim osnovama zasnovane i sprovođenje tehnike podvođenja i zavođenja reklamom. U situaciji kad su stege discipline uklonjene i kad se hedonizam svake vrste postavlja kao najvažnija norma, uživanje u prekomernoj hrani postaje jedno od najvećih iskušenja kome on ne može da odoli, posebno zato što ga društvo ne uči da se od toga brani već ga podstiče da se tom opakom zadovoljstvu predaje. $\mathrm{U}$ isto vreme, nedostaje mu i vremena i volje da se bavi dodatnim fizičkim aktivnostima koje bi mu omogućile da tu prekomernu energiju potroši.

Izneta argumentacija pokazuje zašto je problem autonomije postao tako složen. Lako se uočava da apstraktno postavljanje autonomije, koje naprosto određuje da je čovek slobodan da o ovakvim stvarima sam donosi racionalan sud, nije odgovarajući put za razumevanje načina na koji savremeni svet funkcioniše. Čini se da država, društvo i porodica imaju danas mnogo teži zadatak da mladu osobu formiraju kao autonomnu osobu koja racionalno odlučuje o svojim činovima. Štaviše, izgleda da je određena doza paternalizma u smislu zaštite pojedinca bilo edukacijom, upozorenjima, zabranama ili destimulacijom neophodna i kod punoletnih osoba.

Pitanje ovakve hrane i njenog ovakvog tretmana sve više mora da ulazi u kategoriju u koju potpadaju supstance koje izazivaju zavisnost. Treba se podsetiti na veliku debatu koja je šezdesetih godina vođena oko problema pušenja. Veliki broj mislilaca, kao i same kompanije, branile su apsolutnu slobodu pojedinca da autonomno odlučuje da li će i u kojoj meri da uzima duvan. Bila su čak i publikovana istraživanja koja 
dokazuju kako navodno pušenje ne ugrožava zdravlje. Drugi su tvrdili da pojedinac ima pravo da čak, i u slučaju kad se dokaže da pušenje ugrožava zdravlje, nastavi da ga upražnjava po slobodnom izboru. Tek kada su ozbiljna istraživanja pokazala da nikotin izaziva zavisnost, kao i da podstiče oboljenja pluća, uključujući i rak, ovakvi glasovi su utihnuli i postignut je teško stvoreni konsenzus da je državni paternalizam dozvoljen i potreban kad je u pitanju destimulacija, odnosno obeshrabrivanje pušenja. Tek od tada je postalo legitimno da država vodi kampanje protiv pušenja, da povećava akcize i poreze na njih kako bi ih učinila luksuzom (ubirajući time sredstva koja idu za troškove lečenja bolesti koje pušenje izaziva), da zabranjuje reklamiranje cigareta (kao i žestokih alkoholnih pića), da ograničava i suzbija prostor u kome je pušenje dozvoljeno, da brani takozvane nenameravane, sekundarne pušače, odnosno osobe koje se nalaze u prisustvu onih koji puše, i, konačno, da propisuje regulativu kojom proizvođače cigareta obavezuje da na brutalan način upozoravaju svoje kupce na štetne posledice aktivnosti koju podstiču.

Pitanje pušenja je dobro poznati primer koji sam naveo zbog prirode debate i argumentacije koja veoma podseća na početke javnih i filozofskih debata o tretmanu gojaznosti. Slične ideje su se čule i tokom uspostavljanja prakse prinudnog vezivanja pojaseva u automobolima, kao i u vezi sa uvođenjem obaveznog nošenja zaštitnih kaciga za motocikliste.

Postoji, naravno, još radikalniji primer za totalni paternalizam države koja određene supstance zabranjuje i krivično kažnjava njihovu prodaju, pa čak i uživanje. Radi se, naravno, o raznim vrstama droga. Danas je malo onih, čak i među libertarijancima, koji će se založiti za punu autonomiju osoba da slobodno odlučuju o korišćenju droga.

Ukratko, čini se da je pogrešna teza da ukoliko država i društvo ne učestvuju u ovim pitanjima, pojedinac ostaje da sam autonomno odlučuje o kompleksu pitanja ishrane. Upravo obrnuto: on tada biva izložen suptilnoj i manipulativnoj heteronomiji opake vrste (navođenje na prežderavanje i nezdravu ishranu), od koje veliki deo populacije očigledno nije sposoban da se odbrani. Moja argumentacija u ovoj problematici ide u pravcu tvrdnje da država mora da se meša kako bi branila i razvijala autonomiju pojedinca, da bi u konačnom zbiru branila društvo. ${ }^{18}$ Ona se, međutim, danas meša na uglavnom pogrešne načine.

18 Zalaganje da se neki elementi ishrane tretiraju kao opasnost jednaka drogama može izgledati preteranom. Međutim, činilac zavisnosti koji je lako utvrditi u određenim slučajevima zaista povezuje uzročnike gojaznosti sa uživanjem opojnih supstanci. Činilac zavisnosti je nesporno utvrđen kod nekih osoba čak i kad je u pitanju korišćenje kreditnih kartica. U Americi postoje klinike za odvikavanja od te vrste zavisnosti, a ponašanje banaka koje bez ograničenja koriste oglasni prostor za izazivanje i podsticanje masovne potrošnje, za odobravanje kredita klijentima bez ikakvih ograda i garancija i slično, takođe bi moralo vrlo brzo da izazove odbrambenu reakciju društva. Takvo ponašanje banaka i podsticanje klijenata na neograničenu potrošnju sa elementima zavisnosti dovelo je do najveće ekonomske krize u poslednjih osamdeset godina. 
Ako se vratimo na makro perspektivu interesa savremene liberalne države, moramo početi od konstatacije stanja na području koje razmatramo. Ono je, po svim podacima od kojih smo neke gore izneli, katastrofalno. Sistem koji je u poslednjih dvadesetak godina ostavio odlučivanje o ishrani i vežbanju ,,autonomnim“ pojedincima doveo je do značajne deformacije velikog dela populacije: u Americi to ide do trećine čitave populacije i polovine maloletnika. Čak, u Indiji se za oko petinu populacije procenjuje da je gojazno. U svakom slučaju, tendencije su još više zastrašujuće, a šteta koju društva i države trpe je višestruka. Pogledajmo samo neke segmente.

Radikalno je ugroženo zdravlje stanovništva. Gojaznost i širenje epidemije povećane masnoće kod ljudi povezano je sa širenjem niza bolesti kardiovaskularnog sistema i pre svega dijabetesa.

Ugroženo zdravlje pojedinaca, očigledno nedovoljno sposobnih da sami vode računa o sopstvenom zdravstvenom stanju, povlači ogromno uvećanje troškova društva za lečenje. Umeren život i uravnotežena ishrana uštedeli bi državi značajna sredstva. S druge strane, osim prehrambenih kompanija, korist od takvih posledica gojaznosti imaju i farmaceutske kompanije za koje su neki spremni da ustvrde kako se radi o jednoj od najopasnijih savremenih globalnih mafija. ${ }^{19}$

Gojaznost takođe ugrožava radnu produktivnost stanovništva. Gojazne osobe su manje pokretne, najčešće manje efikasne u obavljanju svojih poslova i potencijalno sklone češćem izostajanju zbog problema sa zdravljem.

Gojazno stanovništvo sa ugroženim zdravljem predstavlja opasnost za bezbednost zemlje. U SAD se preko $12 \%$ prijavljenih u vojsku odbija zbog prekomerne težine. U manjim zemljama, u kojima prilikom ratova za potrebe odbrane zemlje biva regrutovan veliki deo populacije, sa savremenim tendencijama širenja gojaznosti značajno bi bila umanjena borbena i odbrambena moć države.

Urađena su i ozbiljna istraživanja koja dokazuju kako je kod gojaznih osoba umanjena i količina sperme i njena pokretljivost, pa se gojaznost može dovesti u vezu i sa padom reproduktivnih sposobnosti stanovništva.

Nije najmanje značajna i činjenica moralnog propadanja stanovništva koje, usled reklamokratije, nije sposobno da se odbrani od iskušenja preteranog hedonizma (nezdravog uživanja u prekomernoj hrani). Kvalitet države uvek je vezan za moralnu snagu i disciplinu stanovništva, za njegovu sposobnost da se uzdržava od određenih

19 Nažalost, sve više posla imaju i hirurzi pošto se kao najvažnije metode „lečenja“ gojaznosti primenjuju liposukcija, baj pas na želucu, hirurško smanjenje obima želuca, ili barijatrijska hirurgija. Treba primetiti da se već oformila čitava visokoprofitabilna industrija za „suzbijanje gojaznosti“ (farmaceuti, hirurgija, kozmetika) koja će u budućnosti biti takođe veoma važan lobi za sprečavanje stvarne borbe za njeno ograničavanje relevantnim merama kakve predlažem na kraju teksta. Uzgred, treba primetiti da toliki broj gojaznih ljudi nužno menja uobičajene standarde u pogledu veličine stolica u bioskopu ili na sportskim priredbama, u pogledu dozvoljenog broja putnika u avionu ili osoba koje se voze liftom, u tekstilnoj industriji itd. 
primitivnih poriva kako bi pojedinci energiju mogli da usmeravaju ka stvaralaštvu, borbi i samorealizaciji.

Kad se liberalna država suoči sa ovakvim činjenicama ona će morati da počne da tretira gojaznost kao veliki problem za koji ima legitimno pravo da ga suzbija. Kako to ona radi danas?

Povod za promišljanje na ovu temu jeste nedavna odluka gradskog veća, a zatim i suda u Dandiju, u Škotskoj, kojom se roditeljima sedmoro dece oduzima staranje nad njih četvoro zbog gojaznosti. U Americi je ovakva praksa već uspostavljena u nekim slučajevima. Zvaničnici tvrde da će se vlasti maksimalno uzdržavati i da neće zloupotrebljavati postojeće presedane, ali da će u slučajevima kada procene da je opasnost po dečji život radikalna morati da intervenišu, da oduzimaju decu roditeljima i stavljaju ih pod starateljstvo drugih.

Istovremeno, te iste vlasti sve intenzivnije sprovode politiku koja roditeljima radikalno sužava i oduzima pravo nad kontrolom ponašanja svoje dece. Kao što je poznato, u sve većem broju država širi se zakonodavstvo koje zabranjuje bilo kakav oblik fizičkog kažnjavanja dece, preteći roditeljima da im se i zbog toga mogu oduzeti deca. Poznato je, međutim, da u brojnim slučajevima gojaznosti koji pogađaju tinejdžere roditelji nisu mogli nikako sem zabranama i fizičkim odvajanjem od hrane da obuzdaju svoju decu koja su najveći deo vremena provodila prazneći frižider. Dakle, sužavajući prava roditelja nad kontrolom i instrumentima za oblikovanje dece, gde su fizičke kazne tradicionalno predstavljale poslednju i važnu instancu obuzdavanja, disciplinovanja i kanalisanja volje, vlasti im oduzimaju i važno sredstvo za obrazovanje, izgradnju autoriteta, pa i za pravilan fizički razvoj.

Videli smo, dakle, da su vlasti u Britaniji i SAD vrlo lako pribegle radikalnim merama navodnog suzbijanja gojaznosti, a da nisu pokušale sa čitavim nizom drugih mera kojima bi pomogli i roditeljima i deci da se zajedno bore protiv ove epidemije. Ukratko, većina mera koje se danas preduzimaju idu u pravcu podizanja opšte društvene svesti i propagiranja zdravog života, s jedne, te proglašenja gojaznosti oblikom roditeljskog zapostavljanja dece, s druge strane. Dakle u oba slučaja ostaje model pretpostavke pune autonomije pojedinca i pripisivanja apsolutne odgovornosti roditelja za gojaznost deteta, za šta se autonomni roditelji mogu kazniti oduzimanjem ,zanemarene“ dece. ${ }^{20}$

${ }^{20}$ U svom zanimljivom radu Tibo Bosi je analizirao tretman gojaznosti u Francuskoj i Engleskoj. U obe zemlje ona se dugo smatrala posledicom lošeg i moralno neprihvatljivog individualnog ponašanja. Problem je teškom mukom stavljen na političku agendu nakon promene definicija gojaznosti. Ova promena je bila rezultat političke mobilizacije stručnjaka, pre svega epidemiologa i nutricionista koji su bili u stanju da predstave gojaznost kao složen problem koji zahteva političku pažnju i tretman, a ne samo kao moralni problem koji sve ostavlja promeni individualnog ponašanja pojedinca. No, uprkos delimičnim promenama, kao što ćemo i ovde pokazati, i Bosi tvrdi da nije došlo do suštinske izmene u tretmanu uzroka, jer su javne politike prema gojaznosti i dalje suštinski individualizovane. Vidi Bossy (2010). 
Prostor koji liberalna država, s druge strane, malo koristi jeste borba za izmenu čitavog okruženja u kome roditelji delaju i u kome se i oni i deca razvijaju. Ako se pogleda zvanična stranica Britanske vlade ${ }^{21}$ koja govori o gojaznosti, koja se apostrofira kao jedan od najvećih problema javnog zdravlja, naći ćemo nekoliko mera koje ministarstvo preduzima za njeno suzbijanje. Tu je najpre javna kampanja Promena za život (Change 4 Life), koja promoviše zdravu težinu i ohrabruje ljude da se zdravo hrane i da se više kreću. Na sajtu se nude recepti, promovišu vežbe itd. Druga kampanja je uključivanje prodavnica u ovaj program. Zainteresovane prodavnice (oko 227) dobile su pravo na korišćenje brenda Change 4 Life i uz pomoć njega prodaju zdravu hranu, pre svega sveže voće i povrće. U planu je da se od aprila 2011. ova akcija proširi. Uveden je Nacionalni program merenja dece (kao što su kod nas redovni sistematski pregledi) sa idejom da se prati kretanje dece i da ljudi iz ovog programa sarađuju sa roditeljima u praćenju kretanja težine dece, te da na vreme blagovremeno uočavaju potencijalne probleme. Formiran je Centar za učenje o gojaznosti, gde mogu da se informišu i obuče svi zainteresovani za borbu sa ovim problemom. Oformljen je i Nacionalni tim za podršku po pitanjima dečje gojaznosti, koji prati rad lokalnih organa i pomaže im da se stvori atmosfera zdravijeg života. Postoji i Nacionalna opservatorija gojaznosti, gde se slivaju svi relevantni podaci.

Iz svega ovog se da zaključiti da je formirana nova birokratija koja uglavnom prati i savetima pomaže već postojeću strukturu, koja je i dovela do sadašnjeg stanja. Jedina ozbiljna mera koja ide u pravcu suzbijanja izvora jesu pokušaji da se reguliše reklamiranje i oglašavanje hrane kad su deca u pitanju. Vlada je počela da radi sa Ofkomom (britansko regulatorno telo za elektronske medije slično srpskoj $R R A$ ), kako bi osigurala da se na televiziji i drugim medijima promoviše zdravija hrana. Na elektronskim medijima Ofkom je počeo da koristi model profilisanja hranljivosti namirnica kako bi suzbio oglašavanje deci proizvoda koji su prepuni masti, šećera i soli. Tokom jeseni 2011, vlade Francuske i Mađarske uvele su posebne poreze na takvu hranu i napitke, kao što su gazirani napici i grickalice, ${ }^{22}$ oni koji imaju previše soli i šećera. U Mađarskoj je ovo nazvano čips porezom. Time se pokušava da se destimuliše upotreba takvih napitaka, odnosno da se povećanim porezom ovakvi proizvodi učine manje dostupnim širokoj populaciji. Ovo je, čini se, pravac u kome se može i treba kretati ako želimo da suzbijemo bolest gojaznosti.

Da na kraju rezimiramo argument. Čini se da smo ovde dokazali kako liberalna država mora da brine o zdravlju svog stanovništva, te stoga ima legitimno pravo i obavezu da svoju populaciju štiti od gojaznosti. Ona to ne može da postigne ako jednostavno postulira hipotezu o apsolutnoj autonomiji pojedinca i njegovoj ličnoj i isključivoj odgovornosti za ponašanje i fizičko stanje sebe i sopstvene dece, ako ne

${ }^{21}$ http://www.dh.gov.uk/en/Publichealth/Obesity/index.htm

22 Francuska je još 2005. uvela zakon koji zabranjuje postavljanje automata za prodaju grickalica, čokolada i gaziranih napitaka u javnim školama. 
vodi računa o izgradnji njegove autonomije i stvaranju okruženja koje ne podstiče primitivne instinkte kod njega. Najveći prostor i zadatak liberalna država danas bi morala da ima u suzbijanju štetnog delovanja heteronomnih podsticaja koji zarad profita podstiču kod pojedinaca nagone za prežderavanjem.

Deo priče je i činjenica da je na tržištu prisutno preobilje jeftine hrane sumnjivog porekla (genetski modifikovane ili brze), koja se nudi širokim masama siromašnijeg stanovništva, dok zdrava ili organska hrana, koje ima daleko manje u ponudi, postaje luksuz rezervisan za više slojeve sa dubljim džepom.

Liberalna država, dakle, ima pravo i obavezu da se meša u politiku ishrane i čuvanja zdravlja populacije, ali mora da promeni način na koji to radi. Da bi lekovi bili adekvatni mora se izvršiti relevantna dijagnoza stvarnih uzroka i onda se mora usmeriti na njih. Najbolji lek je uvek stvarna prevencija. ${ }^{23}$ Oslanjanje na veru u to da će bilo kakvom akcijom osvešćivanja pojedinci razviti dovoljnu svest da se odupru iskušenjima gojaznosti nije put koji će dati rezultate. Poslednjih trideset godina su to dobro pokazale. Osvešćivanje o razmerama ovog problema treba da bude stalno prisutno na svim nivoima obrazovanja i u javnoj sferi. Treba takođe povećati nivo fizičke aktivnosti kad su deca i omladina u pitanju.

Međutim, država mora da pre svega povede računa o kvalitetu hrane koja se nudi, da suzbija nezdravu hranu visokim porezima, da zabranjuje njeno reklamiranje i sprovodi slične mere kojima se njena upotreba destimuliše. Određene vrste hrane i napitaka moraju se zaista tretirati kao cigarete ili drugi oblici opojnih i štetnih supstanci, pa čak i kao droga. U takvim slučajevima, paternalizam je čak i u liberalnim državama sasvim opravdan. ${ }^{24}$

Na kraju bih podsetio da je hrišćanstvo u uskoj vezi sa razvojem klasičnog liberalizma i da je predstavljalo normativnu i vrednosnu, pa i metafizičku pozadinu razvoja ove ideologije. Stoga bi verske zajednice, a na zapadu posebno hrišćanske, mogle da imaju veliku ulogu u borbi protiv gojaznosti. One neumerenost u jelu odnosno proždrljivost tretiraju kao smrtni greh, a u najvažnijoj hrišćanskoj molitvi se mudro nagovešćuje i relevantan put za suzbijanje:

„I ne dovedi nas u iskušenje...“

${ }^{23}$ Lekari su utvrdili da nema dokaza kako bilo koje farmakološko sredstvo zaista pomaže u lečenju i suzbijanju gojaznosti. Vidi Banićević i dr. (2007), str. 42.

24 Ovo, naravno, nije bilo temeljito istraživanje svih uzroka gojaznosti. U nekim slučajevima je to genetsko nasleđe, u drugim su stres i ostala psihička oboljenja. Postoje svakako i neki drugi, ali uzroci koje sam naveo i kojima sam se bavio čine ipak najvažnije izazivače savremene gojaznosti. 


\section{OBESITY AS POLITICAL AND THEORETICAL PROBLEM}

Abstract: Spread of obesity and diseases that it causes brought to justified warnings of an epidemic. Author starts from classical liberal differentiation between self regarding and others regarding acts, and then raises the issue of the possible liberal approach to obesity problem. He presents real causes of the obesity, and proceeds with two different visions of contemporary liberalism: one, abstract, which doesn't pay attention to context in which we have to draw the line between self and others regarding acts, and second, advanced, responsible liberalism of contemporary liberal democratic state which cares a lot about the context, including international one. From the first perspective state would be obliged not to interfere in overweight problems of its citizens. From the second it would be forced to do so for many substantial reasons. Although author justifies right and even duty of the state to deal with obesity problem, he insists that for the time being it is mostly reacting in wrong way: since idea of individual autonomy is not perceived in adequate way, state reacts to the consequences and not to the causes of the problem.

Key words: obesity, liberalism, limits of state intervention, food

\section{LITERATURA}

Banićević, M., i dr., Projekat: prevencija i lečenje gojaznosti kod dece i adolescenata u Srbiji, Specijalna bolnica Čigota, Zlatibor, 2007.

Boaz, D., Libertarijanizam, Centar za liberalno-demokratske studije, Beograd, 2003.

Bossy, T., Obesity as a Moral Issue: The Agenda-Setting of Obesity in England and France, http://www.ecprnet.eu/MyECPR/proposals/reykjavik/uploads/papers/2367.pdf, 2010.

Dargent, J., Le corps obèse: obésité, science et culture, Editions Champ Vallon, 2005.

Dawson, A., Verwei, M., "The Steward of the Millian State", Public Health, vol. 1/3, 2008, str. 193-195.

Dworkin, G., "Paternalism", Stanford Encyclopedia of Philosophy, 2005, http://plato.stanford. edu/entries/paternalism/

Đurković, M., Kapitalizam, liberalizam i država, Filip Višnjić, Beograd, 2005.

Humbolt, V., fon, Ideje za pokušaj određivanja granica delotvornosti države, Izdavačka knjižarnica Zorana Stojanovića, Sremski Karlovci, 1991.

Kersh, R., Morone, J., "How the Personal Becomes Political: Prohibitions, Public Health and Obesity", Studies in American Political Development, 16, jesen 2002, str. 162-175.

Mil, Dž., S., O Slobodi, Plato, Beograd, 1998.

Callaghann, V. "Putting the Welfare State on a Diet: The Obesity Epidemic in Canada", 2001, http://www.inter-disciplinary.net/wp-content/uploads/2011/08/callaghanfpaper.pdf

Polanji, K., Velika transformacija, Filip Višnjić, Beograd, 2003.

Purcell, M., Raising Healthy Children: Re-interpreting Moral and Political Responsibility for Childhood Obesity and Chronic Disease, neobjavljena magistarska teza, Univerzitet Viktorija, 2008. http://dspace.library.uvic.ca:8080/bitstream/handle/1828/1040/ M?sequence $=1$ 
Rubino, A., „Bolesti dece i adolescenata u savremenoj civilizaciji - „druga strana medalje“, Medicinski glasnik, Zlatibor, br. 34, mart 2010, str. 11-12.

Spurlock, M., Super Size Me, dugometražni dokumentarni film, 2004. 